\title{
Study of Cell Tower Radiation and its Health Hazards on human body
}

\author{
Lalrinthara Pachuau ${ }^{1}$, Zaithanzauva Pachuau ${ }^{2}$

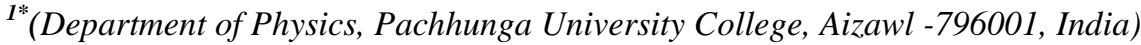 \\ ${ }^{2}$ (Department of Physics, Mizoram University, Tanhril-796004, India)
}

\begin{abstract}
In this paper, we present the study of RF radiation from mobile tower and its health effects on human body. Power density of RF radiation from a mobile tower have been measured in close proximity to the mobile base station (GSM 900) at the selected locality in Aizawl, Mizoram, India, which was erected in 2009. Questionnaire was conducted on different health problems faced by the inhabitants living near the base station. The absolute power densities have been measured at different houses which is compared with standard limits given by various authorities like International Commission on Non Ionizing Radiation Protection (ICNIRP), Bioinitiative : 2012 and with the current Indian Standards. Frequency spectrum was analysed at different sites. Different health symptoms of RF exposure faced by the inhabitants within $50 \mathrm{~m}$ and outside $50 \mathrm{~m}$ from the tower are analysed and compared. The result is also analysed based on sex. It was found that the inhabitants living within $50 \mathrm{~m}$ are having more health complaints than those living outside 50m. It was also found that females are having more complaints than males. This type of study is the first time report in the state.
\end{abstract}

Keywords: $R F$, Non ionizing radiation, Power density, Frequency spectrum, base stations.

\section{Introduction :}

Cellular wireless telephones have become ubiquitous. Wireless technology is based on extensive networks of base stations that connect the users through Radio Frequency (RF) signals. Over the last decade, there has been a great deal of concern about possible health consequences caused by human exposure to RF in general and radiations from base stations in particular ${ }^{[1],[2],[3]}$. It is believed that mobile phones produce RF energy of non-ionizing radiation which is too low to heat the body's tissues, and hence is unlikely to have the same impact on human health as those produced by ionizing radiations such as X-rays ${ }^{[4]}$. Nonetheless, there is still a need to determine the level of health risks caused by RF radiations. Many studies address the impact of mobile phone radiations on human body, only a few consider the effect of human exposure to base stations although such an effect may be greater as more body parts can absorb RF energy ${ }^{2}$.

With the significant increase in mobile phone usage, possible health risks related to RF exposure have become the subject of considerable attention ${ }^{[3],[5]}$. This includes effect from exposure to both cell phones and base stations. Health concerns can be divided into two main categories : short term and long term effects. The short term effect includes brain electrical activity, cognitive function, sleep, heart rate and blood pressure ${ }^{[6]}$. However, the long term effects includes tinnitus, headache, dizziness, fatigue, sensations of warmth, dysesthesia of the scalp, visual symptoms, memory loss and sleep disturbance, muscle problem and epidemicological effects including cancer and brain tumours ${ }^{[7],[8]}$.

In May 2011, International Agency for Research on Cancer (IARC) has classified RF field as possibly carcinogenic to human (group 2B) based on increased risk for glioma, a malignant type of brain cancer associated with wireless phone use ${ }^{[9]}$.

\subsection{Questionnaire}

II. Materials and Methods:

To study the health hazards and problems faced by the inhabitants living close to the base station (all living within $100 \mathrm{~m}$ ), questionnaire survey was conducted on 12 different symptoms at the selected site on the eastern part of Aizawl. The questionnaire was similar to that developed for the study on mobile phone users $^{[9],[10]}$. The survey was conducted on 12 different houses on 64 adult persons ( 31 female, 33 male). The level of complaints for the studied symptoms was expressed by using a scale of: $0=$ never, $1=$ sometimes, $2=$ often, 3 = very often. Health hazards faced by the inhabitants were analysed and comparisons have been made based on sex distance (less than $50 \mathrm{~m}$ and more than $50 \mathrm{~m}$ ).

\subsection{Power density measurement:}

Power density measurement was carried out on some selected different houses in close proximity to the base station. The main purpose of the measurement is to ensure that RF field emission from each site does not 
exceed the public limits and to find any correlation between the health complaints and the power density. The power density $\mathrm{P}_{\mathrm{d}}$ of the RF energy is given by ${ }^{[11]}$

$$
P_{d}=\frac{n P_{t} G}{4 \pi D^{2}}
$$

where $\mathrm{n}=$ Number of transmitters, $\mathrm{P}_{\mathrm{t}}=$ Maximum power from each transmitter, $\mathrm{G}=$ Antenna

gain (in decibel), $\mathrm{D}=$ Distance of the site from the transmitter. The power density measurement was done with the instrument HF-60105V4, manufactured by Aaronia, Germany.

\subsection{Frequency spectrum}

Frequency spectrum of the radiation have been recorded at different houses. The same instrument HF$60105 \mathrm{~V} 4$, manufactured by Aaronia, Germany was used to analyse the frequency spectrum. The instrument is capable of measuring non-ionizing radiation for frequency range of $1 \mathrm{MHz}$ to $9.4 \mathrm{GHz}$. In the selected site, other than RF radiation, the other electromagnetic signals present were of TV and Radio which lie outside the GSM 900 frequency range. Hence it has been assumed that the peaks observed were of RF radiation only.

\subsection{Analysis of questionnaire}

\section{Results and discussions}

Analysis of the questionnaire is given in Tables 1, 2 and 3. Scale number 2 and 3 are given more considerations. From Tables 1 and 2, it is found that from 12 different symptoms studied, for within and outside $50 \mathrm{~m}$ from the tower, females are having more complaints than males. Within $50 \mathrm{~m}$ (Table-1) on scale 2, out of 12 symptoms females are having more complaints on 8 symptoms; on scale 3, females are having more complaints on 3 symptoms. Outside 50m (Table-2), females are having more complaints again. The complaints with more frequencies are fatigue, nausea, dizziness and muscle pain. These 4 symptoms (for less than $50 \mathrm{~m}$ ) are given in figures 1-4 for both the sexes (for scales 2 and 3). Comparison of complaints between all the individuals living within $50 \mathrm{~m}$ and outside $50 \mathrm{~m}$ is given in Table 3 . It has been observed that those living within $50 \mathrm{~m}$ from the base station are having more health complaints than those living outside $50 \mathrm{~m}$ for which the graph is given in Figure 6.

Table 1 : Comparison of complaints between male (25) and female (21) living near the base station within $50 \mathrm{~m}$ (all the figures are in percentage).

\begin{tabular}{|c|c|c|c|c|c|c|c|c|c|}
\hline \multirow{2}{*}{$\begin{array}{l}\text { Sl. } \\
\text { No. }\end{array}$} & \multirow[t]{2}{*}{ Symptom } & \multicolumn{2}{|c|}{$\mathbf{0}$} & \multicolumn{2}{|c|}{1} & \multicolumn{2}{|c|}{2} & \multicolumn{2}{|c|}{3} \\
\hline & & $\mathbf{M}$ & $\mathbf{F}$ & $\mathbf{M}$ & $\mathbf{F}$ & $\mathbf{M}$ & $\mathbf{F}$ & $\mathbf{M}$ & $\mathbf{F}$ \\
\hline 1. & Fatigue & 44 & 23.8 & 28 & 47.6 & 20 & 9.5 & 12 & 19 \\
\hline 2. & Nausea & 40 & 38 & 40 & 38 & 12 & 14.3 & 4 & 9.5 \\
\hline 3. & Sleep disruption & 36 & 23.8 & 16 & 28.6 & 20 & 23.8 & 24 & 23.8 \\
\hline 4. & Feeling of discomfort & 56 & 42.8 & 20 & 38 & 6 & 19 & 12 & 0 \\
\hline 5. & Headache & 36 & 14.3 & 48 & 57 & 12 & 9.5 & 0 & 19 \\
\hline 6. & Difficulty in concentration & 28 & 28.6 & 40 & 52.4 & 16 & 19 & 12 & 0 \\
\hline 7. & Memory loss & 32 & 23.8 & 40 & 47.7 & 16 & 23.8 & 8 & 4.7 \\
\hline 8. & Skin problem & 32 & 33.3 & 32 & 23.8 & 12 & 14.3 & 20 & 4.7 \\
\hline 9. & Visual disruption & 52 & 66.7 & 20 & 14.3 & 12 & 14.3 & 16 & 4.7 \\
\hline 10. & Hearing problem & 60 & 66.7 & 20 & 23.8 & 4 & 9.5 & 12 & 0 \\
\hline 11. & Dizziness & 64 & 33.3 & 24 & 42.8 & 24 & 19 & 24 & 4.7 \\
\hline 12. & Muscle pain & 55 & 43 & 15 & 17 & 17 & 18 & 13 & 22 \\
\hline
\end{tabular}

Reference : $0=$ never, $1=$ sometimes, $2=$ often, 3 = very often 
Table 2 : Comparison of complaints between male (10) and female (8) living near the base station outside $50 \mathrm{~m}$ (all the figures are in percentage).

\begin{tabular}{|c|c|c|c|c|c|c|c|c|c|}
\hline \multirow{2}{*}{$\begin{array}{c}\text { Sl. } \\
\text { No. }\end{array}$} & \multirow[t]{2}{*}{ Symptom } & \multicolumn{2}{|c|}{$\mathbf{0}$} & \multicolumn{2}{|c|}{$\mathbf{1}$} & \multicolumn{2}{|c|}{2} & \multicolumn{2}{|c|}{3} \\
\hline & & $\mathbf{M}$ & $\mathbf{F}$ & $\mathbf{M}$ & $\mathbf{F}$ & $\mathbf{M}$ & $\mathbf{F}$ & $\mathbf{M}$ & $\mathbf{F}$ \\
\hline 1. & Fatigue & 75 & 80 & 12.5 & 10 & 10 & 12.5 & 0 & 0 \\
\hline 2. & Nausea & 75 & 80 & 12.5 & 10 & 10 & 0 & 12.5 & 0 \\
\hline 3. & Sleep disruption & 50 & 80 & 37.5 & 10 & 10 & 12.5 & 0 & 0 \\
\hline 4. & Feeling of discomfort & 62.5 & 90 & 25 & 0 & 10 & 12.5 & 0 & 0 \\
\hline 5. & Headache & 50 & 90 & 37 & 0 & 10 & 12.5 & 0 & 0 \\
\hline 6. & Difficulty in concentration & 62.5 & 70 & 25 & 20 & 10 & 12.5 & 0 & 0 \\
\hline 7. & Memory loss & 50 & 80 & 50 & 20 & 0 & 0 & 0 & 0 \\
\hline 8. & Skin problem & 37.5 & 100 & 50 & 0 & 0 & 12.5 & 0 & 0 \\
\hline 9. & Visual disruption & 37.5 & 80 & 37.5 & 20 & 0 & 25 & 0 & 0 \\
\hline 10. & Hearing problem & 50 & 100 & 37.5 & 0 & 0 & 12.5 & 0 & 0 \\
\hline 11. & Dizziness & 37.5 & 100 & 37.5 & 0 & 0 & 25 & 0 & 0 \\
\hline 12. & Muscle pain & 62 & 57 & 22 & 18 & 10 & 15 & 6 & 10 \\
\hline
\end{tabular}

Reference : $0=$ never, $1=$ sometimes, 2 = often, 3 = very often

Table 3 - Comparison of complaints from all the individuals (64) based on distance (in percentage).

\begin{tabular}{|c|c|c|c|c|c|c|c|c|c|}
\hline \multirow{2}{*}{$\begin{array}{l}\text { Sl. } \\
\text { No. }\end{array}$} & \multirow[t]{2}{*}{ Symptom } & \multicolumn{2}{|c|}{$\mathbf{0}$} & \multicolumn{2}{|c|}{1} & \multicolumn{2}{|c|}{2} & \multicolumn{2}{|c|}{3} \\
\hline & & $<50 \mathrm{~m}$ & $>50 \mathrm{~m}$ & $<50 \mathrm{~m}$ & $>50 \mathrm{~m}$ & $<50 \mathrm{~m}$ & $>50 \mathrm{~m}$ & $<50 \mathrm{~m}$ & $>50 \mathrm{~m}$ \\
\hline 1. & Fatigue & 34.7 & 78 & 37 & 11 & 13 & 11 & 15 & 0 \\
\hline 3. & Sleep disruption & 30.4 & 67 & 22 & 22 & 22 & 11 & 26 & 0 \\
\hline 4. & Feeling of discomfort & 50 & 78 & 28 & 11 & 13 & 11 & 6.5 & 0 \\
\hline 6. & Difficulty in & 28 & 67 & 45.6 & 22 & 17.3 & 11 & 6.5 & 0 \\
\hline 7. & Memory loss & 28 & 67 & 43 & 33 & 19.6 & 0 & 6.5 & 0 \\
\hline 8. & Skin problem & 33 & 72 & 28 & 22 & 13 & 6.5 & 13 & 0 \\
\hline 9. & Visual disruption & 58.7 & 61 & 17 & 28 & 13 & 11 & 11 & 0 \\
\hline
\end{tabular}

Reference : $0=$ never, $1=$ sometimes, $2=$ often, $3=$ very often

Figures 1 - 4 : Comparison of complaints for male and female within $50 \mathrm{~m}$ from the base station (all the figures are for those living within $50 \mathrm{~m}$ from the base station).

Reference : $\square=$ Male $\square=$ Female

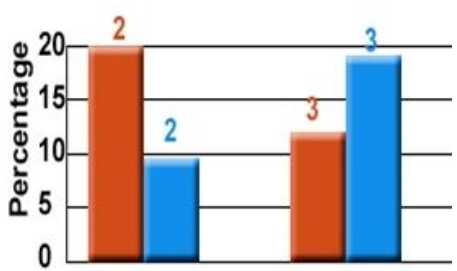

Fatigue

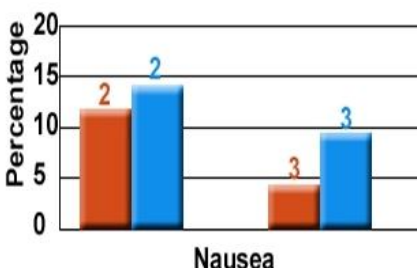

Fig. 2 


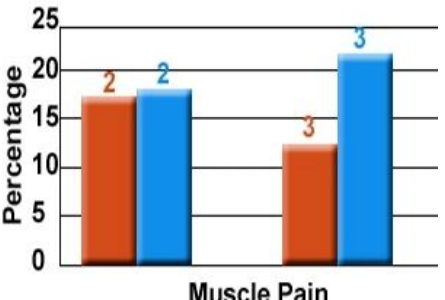

Fig. 3

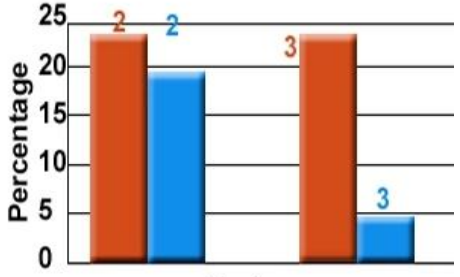

Dizziness

Fig. 4

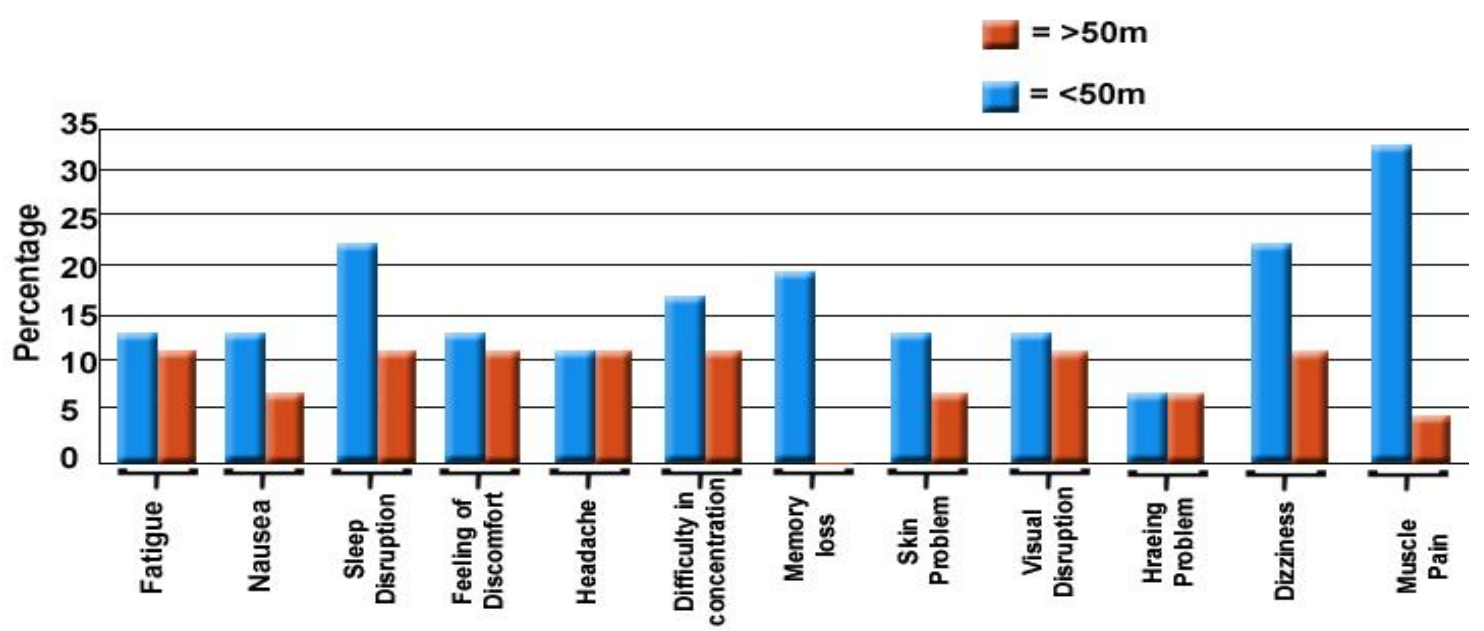

Fig. 5 : Comparison of complaints from all the individuals based on distance

\subsection{Power density measurement :}

Power density of the RF radiation from the selected tower was measured at different selected houses. The highest measured value was $21 \mathrm{~mW} / \mathrm{m}^{2}$. Most of the measured values are higher than that of the safe limits recommended by Bioinitive Report $2012\left(0.5 \mathrm{~mW} / \mathrm{m}^{2}\right)^{[12]}$, Salzburg resolution $2000\left(1 \mathrm{~mW} / \mathrm{m}^{2}\right)^{[13]}$, EU (STOA) $2001\left(0.1 \mathrm{~mW} / \mathrm{m}^{2}\right)^{[13]}$. However, all the measured values were well below the current ICNIRP safe level $\left(4700 \mathrm{~mW} / \mathrm{m}^{2}\right)^{[13]}$ and the current Indian Standard $\left(450 \mathrm{~mW} / \mathrm{m}^{2}\right)^{[14]}$. Measured power densities depend to a large extent on the obstructing materials like furnitures, buildings, walls and orientation of the building. That is why the measured power densities vary from place to place. The measured value of power density at different houses is given in Table 4.

Table 4: Measured values of Power density at different houses (all the houses are of RCC type)

\begin{tabular}{|c|c|c|c|c|c|c|c|c|c|}
\hline $\begin{array}{l}\text { Sl. } \\
\text { No. }\end{array}$ & $\begin{array}{c}\text { House } \\
\text { /Nature of } \\
\text { House }\end{array}$ & $\begin{array}{l}\text { Distance } \\
\text { from the } \\
\text { tower }(m)\end{array}$ & $\begin{array}{l}\text { Exact site of } \\
\text { measurement }\end{array}$ & $\begin{array}{c}\text { Power } \\
\text { density } \\
\left(\mathbf{m W} / \mathbf{m}^{2}\right)\end{array}$ & $\begin{array}{l}\text { Power } \\
\text { (dBm) }\end{array}$ & $\begin{array}{c}\% \text { wrt } \\
\text { ICNIRP }\end{array}$ & $\begin{array}{c}\text { \% wrt } \\
\text { Indian } \\
\text { Standard }\end{array}$ & $\begin{array}{c}\% \text { wrt } \\
\text { Bioinitiativ } \\
\text { e Report } \\
2012\end{array}$ & $\begin{array}{c}\text { Main complaints of } \\
\text { inhabitants of the } \\
\text { house }\end{array}$ \\
\hline 1. & $\begin{array}{l}\text { RBI Office } \\
\text { /RCC }\end{array}$ & 55 & Living Room & 2.4 & -17 & 0.051 & 0.53 & 480 & $\begin{array}{l}\text { Muscle pain, } \\
\text { Fatigue }\end{array}$ \\
\hline \multirow[t]{2}{*}{2.} & \multirow{2}{*}{$\begin{array}{l}\text { Residence- } \\
1 / \text { RCC }\end{array}$} & \multirow[t]{2}{*}{74} & Living Room & 1.5 & -19 & 0.032 & 0.33 & 300 & \multirow{2}{*}{$\begin{array}{l}\text { Muscle pain, } \\
\text { Fatigue, Sleep } \\
\text { disorder, Nausea }\end{array}$} \\
\hline & & & Balcony & 21 & & 0.445 & 4.67 & 4200 & \\
\hline \multirow[t]{3}{*}{3.} & \multirow{3}{*}{$\begin{array}{l}\text { Residence- } \\
\text { 2/RCC }\end{array}$} & \multirow[t]{3}{*}{15} & Kitchen & 12.2 & -10 & 0.260 & 2.71 & 2440 & \multirow{3}{*}{$\begin{array}{l}\text { Skin problem, } \\
\text { Fatigue, Muscle } \\
\text { pain, Dizziness, } \\
\text { Sleep disorder }\end{array}$} \\
\hline & & & Bed Room-1 & 12.3 & -10 & 0.262 & 2.73 & 2460 & \\
\hline & & & Living Room & 1.88 & -18 & 0.040 & 0.42 & 376 & \\
\hline \multirow[t]{2}{*}{4.} & \multirow{2}{*}{$\begin{array}{l}\text { Residence- } \\
\text { 3/RCC }\end{array}$} & \multirow[t]{2}{*}{59} & Bed Room-1 & 1.95 & -18 & 0.415 & 0.43 & 390 & \multirow{2}{*}{$\begin{array}{l}\text { Muscle pain, } \\
\text { Nausea, Fatigue, } \\
\text { Sleep disorder }\end{array}$} \\
\hline & & & Kitchen & 1.69 & -19 & 0.360 & 0.37 & 338 & \\
\hline 5. & $\begin{array}{l}\text { Residence- } \\
4 \\
\text { /RCC }\end{array}$ & 23 & Living Room & 2.1 & -18 & 0.044 & 0.47 & 420 & $\begin{array}{l}\text { Muscle pain, Sleep } \\
\text { disruption, Fatigue, } \\
\text { Feeling of } \\
\text { discomfort }\end{array}$ \\
\hline 6. & $\begin{array}{l}\text { CHSS } \\
\text { /RCC }\end{array}$ & 93 & Main Office & 0.0018 & -48 & 0.00004 & 0.0004 & 0.36 & No complaints \\
\hline
\end{tabular}




\subsection{Analysis of Frequency spectrum}

Frequency spectrum of the selected mobile tower was recorded at different places. It has been observed that the peak frequency changes in different places. Many frequency peaks are observed at each site. In the selected site, other than RF radiation, the other electromagnetic signals present were of TV and Radio which lie outside the GSM 900 frequency range. Hence it has been assumed that the peaks observed were of RF radiation only.

Frequency spectrum of the radiation is given in Figures 7 and 8.

Figure $7 \& 8$ : Frequency spectrum of the RF radiation from the tower (GSM 900)

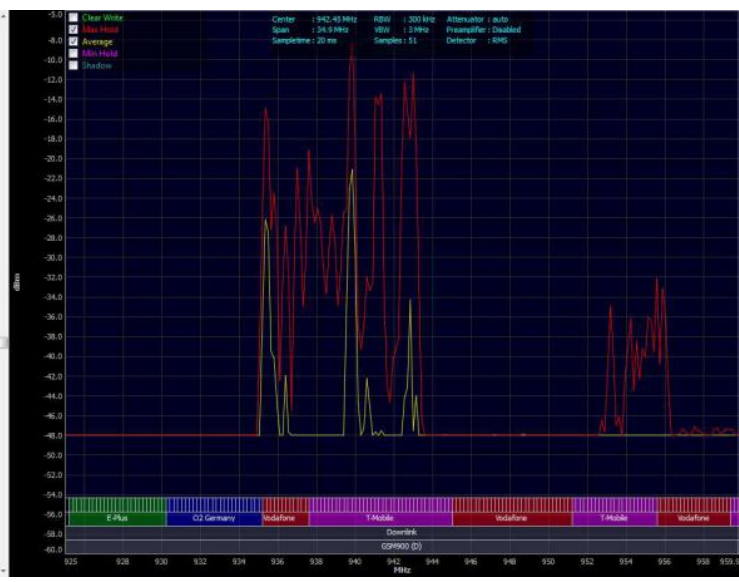

Figure 7

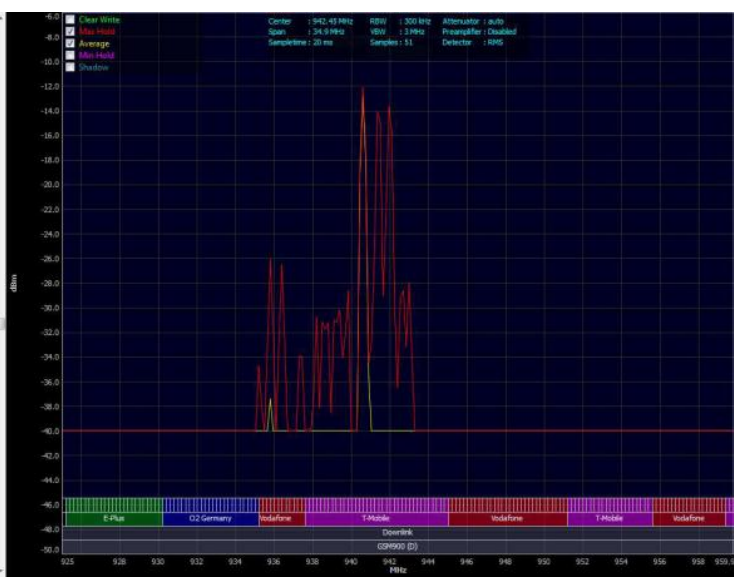

Figure 8

\section{Conclusion}

It has been observed that almost all the measured values of power density at all the sites are higher than that of the safety recommendation of Bioinitiative Report ${ }^{[12]}$, Salzburg resolution $2000^{[13]}$ and EU (STOA) $2001^{[13]}$, but well below the safety limit recommended by ICNIRP $^{13}$ and the Department of Telecommunications, Govt. of India ${ }^{[14]}$. However, through questionnaire it has been observed that many inhabitants are still having health complaints on different symptoms after the tower had been erected (in 2009). It has been observed that females are having more health complaints than males. It has also been observed that those living within $50 \mathrm{~m}$ from the base station are having more health complaints than those living outside $50 \mathrm{~m}$. It may be concluded that mobile tower should not be erected in the populated area. It is suggested that human dwelling should be avoided within $50 \mathrm{~m}$ from the tower.

\section{References}

[1] JF Viel, S Clerc, C Barrera, R Rymzhanova, M Moissonnier, M Hours, E Cardis, Residential exposure to Radiofrequency Fields from Mobile Phone Base stations, and Broadcast Transmitters: A population-Based Survey with Personal Meter, Occup Environ Med 66 (2009) 550-556.

[2] AM Martinez-Gonzalez, A Fernandez-Pascual, Practical Procedure for Verification of Compliance of Digital Mobile Radio Base Stations to Limitations of Exposure of the General Public to Electromagnetic Fields, IEEE Proceedings on Microwaves, Antennas and Propagation (USA) 149 (2002) 218-228.

[3] A Ahlbom, A Green, et al, Epidemiology of Health Effects of Radiofrequency Exposure, Environmental Health Perspectives 112(17), (2004), 1741-1754.

[4] U.S Food and Drug Administration (FDA), Radiation emitting Products: Reducing Exposure : Hands-Free Kits and Other Accessories, 2009.http://www.fda.gov/RadiationEmittingProducts/RadiationEmittingProductsandprocedures/HomeBusinessandEntertainment/CellPhones/ucm116338.htm

[5] Nora D. Volkow, Dardo Tomasi, Gene-Jack Wang, Paul Vaska, Joanna S. Fowler, Frank Telang, Dave Alexoff, Jean Logan and Christopher Wong, Effects of Cell Phone Radiofrequency Signal Exposure on Brain Glucose Metabolism, Journal of American Medical Association, 305(8), 2011, 808-813.

[6] World Health Organisation (WHO) Media Centre, Electromagnetic Fields and Public Health : Mobile Phones, 2011. http://www.who.int/mediacentre/factsheets/fs193/en/

[7] Chia SE, Chia H.P, Tan J.S, Prevalence of Headache Among Handheld Cellular Telephone Users in Singapore : A community Study, Environmental Health Perspectives 108(11), 2000, 1059-1062.

[8] Oftedal G, Wilen G, Sandstrom M, Mild K.H, Symptoms experienced in Connection with Mobile Phone use, Occupational Medicine, 50(4), 2000, 237-245.

[9] International Agency for Research on Cancer, Press release $\mathrm{N}^{\mathrm{o}}$ 208, Lyon, France, 31 ${ }^{\text {st }}$ May 2011. www.iarc.fr/en/mediacentre/pr/2011/pdfs/pr208_E.pdf

[10] R Santini, P Santini, J.M Danze, P Le Ruz, Study of the Health of People living in the vicinity of mobile phone base stations : I. Influences of distance and sex, Pathol Biol 50, 2002, 369-373. 
[11] Muoaaz Nahas, Mohammed T. Simsim, Safety Measurements of Electromagnetic Fields Radiated form Mobile Base Stations in the Western Region of Saudi Arabia, Wireless Engineering Technology, 2, 2011, 221-229.

[12] Cindy Sage, David O. Carpenter, Key Scientific Evidence and Public Health Recommendations, in Cindy Sage and David O. Carpenter (Ed) Bioinitiative 2012 : A Rationale for Biologically-based Public Exposure Standards for Electromagnetic Radiation, edited by (Bioinitiative Working Group, 2012), 1424. www.bioinitiative.org

[13] Haumann Thomas, Munzenberg Uwe et al, HF Radiation levels of GSM Cellular Phone Towers in Residential Areas, hbelc.org/pdf/memdocs/cellularphoneradiation.pdf

[14] Department of Telecommunications, Govt. of India, Advisory Guidelines for State Governments for Issue of clearance for installation of Mobile Towers, 2013. http://www.dot.gov.in/access-services/journey-emf 